\title{
Funding Strategies for Quality University Education in Nigeria: The Principle of Fiscal Justice
}

\author{
Ayo-Sobowale, Mopelola, M.Ed, MPA \\ Department of Educational Management, Lagos State University, Lagos, Nigeria \\ E-mail: smoayobowale@yahoo.com
}

Akinyemi Samuel, PhD, AIMM (corresponding author)

Department of Educational Management, Lagos State University, Lagos, Nigeria

E-mail: akinyemisam2006@yahoo.com

\author{
Received: October $24 \quad$ Accepted: October $31 \quad$ Published: December 1, 2011 \\ doi:10.5296/jse.v1i1.1031ＵRL: http://dx.doi.org/10.5296/jse.v1i1.1031
}

\begin{abstract}
The problem of funding and financing of our universities in Nigeria has become a reoccurring decimal, often times resulting into strikes and closures of the ivory towers. The fact that these problems are yet to be tackled by the government emphasizes the need for universities to evolve strategies for generating additional funds. The Federal Government directed through the National Universities Commission (N.U.C.) that all Federal Universities should generate 10 percent of their total yearly funds internally through various revenue diversification means. In view of the above, this paper examines the funding pattern in relation to qualitative university education in Nigeria, using alternative strategies in generating additional funds. The paper recognizes funding as an external factor in achieving quality university education. Since the pursuit of Quality University education bothers on all stakeholders - the government, parents, individuals, firms and corporate bodies (who are the employers of labour). Based on this, the paper recommended some funding strategies with emphasis on the "Fiscal Justice’ principle of fairness" as a tuition fee strategy. Also private sector participation, partial deregulation and the macroeconomic strategies are other strategies recommended in the paper.
\end{abstract}

Keywords: Funding, University Education, Quality, Strategies, Fiscal Justice Principle of Fairness. 


\section{Introduction}

In today's world, knowledge is valued as the determinant and driver of economic growth, development and competitiveness, and the university education is the major source of providing the required knowledge that will help generate and accelerate knowledge flow for modern based economies. The general growth and development of any given nation are a function of quality of its human resources produced mainly by the system. For these reasons, individual, firm, corporate organizations and governments are faced with investment decisions on regular basis. The concern for quality in university education in Nigeria is most desirable for reasons that are obvious above. University education is the nation's hope for national development.

In Nigeria, university education is the focal point of higher education. It is the type of education given to individuals after secondary level of education which consists of conventional universities offering courses in sciences and humanity and special universities for sciences, agriculture and engineering. The Federal Ministry of Education (2008), reveals that the vision of the Nigerian higher (tertiary) education system has the following expectations: To be (i) relevant and responsive to the need of the society (ii) adequate in quantity and quality with a well motivated, highly skilled and qualified staff whose products are knowledgeable, technically competent and adequately prepared for fulfilled life and for positive contribution in the society.

In Nigeria today, there are about 73 universities, 57 polytechnics and 65 colleges of education. All these institutions of higher education require infrastructure, equipment, resources and personnel. Higher institutions in Nigeria are financed by grants/subventions provided by both state and federal governments, with insignificant contributions collected from students as fees. The business of providing qualitative university education for the Nigerian child should be a collective responsibility of all stakeholders in the education sector. The stakeholders include all who in one way or the other benefit from the programmes and products of the university system.

In this era of globalization and massification of education, Nigeria cannot afford to run a university system that compromises quality if she is to compete in the global economy. Globalization of the world economy is the integration of economies throughout the world through trade, financial flows, exchange of technology information and the movement of people. In order to meet the challenges of the $21^{\text {st }}$ century and absolute internalization, there is the need for education to imbibe the global culture and adopt ardent consideration of development in line with the current technological trends.

Since globalization has occasioned changes in educational pivot role, proved by the fact that contemporary Nigerian education is busy grappling with how to develop strategies that would help in the production of knowledge-based citizens ready to meet the global challenges, there are bound to be changes in educational processes and methods. One of such areas is that of educational funding and financing. Having admitted that education is an instrument for the enhancement of the socio-economic advancement and viability of any nation, changes in educational funding and financing strategies in Nigeria have in fact become imperative. The 
traditional lip-services, poor funding, and embezzlement of funds meant for educational services and development must now become things of the past.

\section{The Concept of Quality in Education}

\subsection{What is Quality?}

It is not easy to give a precise definition of quality in education. Quality is an abstract concept, which implies subjective assessment. However an attempt is made here to offer explanation in the sense in which the term is used in this paper. Quality in education has to do with the quality in educational input and output in its entirety. The quality of the educational system can be assessed by 'how adequate and accessible the facilities and materials needed for effective teaching and learning are available in order to ensure that educational programmes meet up the national objectives.

Quality in education according to Nwanna (2000) refers to the scale of input in the form of funds, equipment facilities, teacher and pupils alike and to the fact that the transaction and output of institutions in the form of their product are acceptable, desirable, beneficial, efficient and effective from the point of view of the government, society, private agencies and stakeholders.

Igwe (2007) sees quality in higher education to cut across policy formulation to implementation of educational process covering the scope of curriculum; teaching/learning process; resources and facilities; students and teachers environment. Again, Igwe (2007) perceives quality in education as "better school environment, more qualified teachers, and adequate supply of textbooks ... relevance to social needs.

Quality is therefore considered as the baseline standard in education, which can be measured on a scale of preference, hence quality is an expression of standard or the mean by which a certain set of standards in education can be achieved (Maduewesi, 2002).

\subsection{Concern for Quality University Education}

The justification for a sound and quality university education cannot be overemphasized. Education is a basic activity of mankind because it is the process by which human beings acquire effective knowledge and skills. The concern for quality in university education in Nigeria is most desirable for the economic, political scientific and technological development and advancement of any nation.

University education is expected to create needed human capital with enhanced skills that can lead to technological innovation, productivity and growth within the economy (Olaniyan, 2001). The quality of human capital has direct impact on the development or otherwise of a system, nation building inclusive. Hence, university education is specially designed to provide the needed manpower for the overall turn around of a nation.

Generally, education, and particularly university education, is fundamental to the construction of a knowledge economy and society in all nations (World Bank, 1999). The business of providing qualitative university education for the Nigerian child should be a collective 
responsibility of all stakeholders in the education sector. The stakeholders include all who in one way or the other benefit from the programmes and products of the university.

The fact that the various governments of the federation cannot adequately fund higher education in the country implies that the institutions must look for other sources of revenue to finance their programmes. The Federal Ministry of Education has observed that university education in Nigeria is in a state of decay (FME, 2000). Government is aware that this decadent situation portends danger to the country, particularly as poor quality graduates who are ill-equipped for the world of work are currently being produced. The Nigerian university system lacks the financial resources to maintain educational quality. In fact, the quality of university education in Nigeria has reduced considerably.

Aina (2002), Babalola (2002) and Samuel (2003) further affirmed that federal universities in Nigeria were lacking the financial resources to maintain educational quality in the face of enrolment explosion. The inadequate funding of the universities has had calamitous effect on teaching and research and has also led to brain drain of the academics. So universities were forced to embark on income generating projects in order to source for funds.

As a means of finding solutions to the unending financial causes in the nation's universities, the Federal Government directed through the National Universities Commission (NUC) that all federal universities should generate 10 percent of their total yearly fund internally through various revenue diversification means (Odebiyi and Aina, 1999). The problem of under-funding and over-reliance on government funds remains a clog in the wheel of university governance in Nigeria (Aina, 2002). All AfricaNews: Nigeria (2006) reported that President Obasanjo called on university administrators to enhance their internal revenue generation as well as seek funds from private organizations, adding that the days of total or even near total reliance on governments funding are over. The above statement implies that the institutions must look for other strategies to finance their programmes. The writer therefore deems it wise to state the government services of fund for our university education.

\subsection{Factors Affecting the Quality of High Education in Nigeria}

The factors that account for the poor quality of university education in Nigeria are both internal and external to the universities. The internal factors include lack of employee motivation, weak accountability for educational performance and management competency, while the external factors include poor funding, teacher shortages and corruption. However, an attempt is made here to offer explanations on the external factors as this paper depicts.

\subsubsection{Funding Pattern}

Funding of higher education in Nigeria at both the state and federal institutions have always been a major and persistent problem. The incidence of poor funding is seen in incessant strikes by Academic Staff Union of Universities and the dearth of curriculum support equipment and facilities. In support of this observation, Ekpo (2002) asserts that there has never been a time that adequate money is sent to match the wage bills. Where learning facilities are not available and lecturers are most of the times on strike as a result of inadequate funding, it is an indication that the product of such academic programmes may not 
meet the standard required.

Inadequate funding of public universities in Nigeria is a prime cause of other problems that have undermined quality in university education. The issue of poor funding has its manifestation in problems such as academic staff shortage, dearth of library books and journals, decline of reading culture among students, dilapidated buildings, obsolete equipment, the desire to obtain degrees by unorthodox means etc. The Nigerian university system lacks the financial resources to maintain educational quality because Nigeria's recent allocation shares for education diverge sharply from regional and international norms. For example, UNESCO's Report (2002) indicates that for 19 other countries of Sub-Saharan Africa, education expenditures averaged 5.1 percent of GDP and 14.3 percent of government expenditure (Hinchiffe, 2002). In fact, Nigeria's funding efforts of education is low and its budgetary priority for the education sector is even lower.

The funding situation in the Nigeria university system in the 1960s and early 1970s' was considered adequate until late 1970s' and early 1980s' when the situation began to change, a situation in the university that is said to be causing considerable tension and stress within the university system during the period, (Onoh, 1982; Abdullah, 1984). Tamuno (1987) observes that where quarterly basis of grants has failed to relieve the heavy burdens of federal universities, the monthly allocation of state universities has caused their state counterparts instant pains in the neck. 
Table 1. Federal Government Budgetary Expenditure on Education as a

Proportion of Federal Government Budget Expenditure (N million)

\begin{tabular}{|l|l|l|l|}
\hline Year & $\begin{array}{l}\text { Total Fed. Govt. } \\
\text { Expenditure } \\
\text { (NM) }\end{array}$ & $\begin{array}{l}\text { Expenditure on } \\
\text { Education } \\
\text { (NM) }\end{array}$ & $\begin{array}{l}\text { Expenditure on Education } \\
\text { as of the Total } \\
\text { Expenditure }\end{array}$ \\
\hline 1988 & $20,290.80$ & 190.10 & 5.37 \\
\hline 1989 & $27,392.20$ & $1,941.80$ & 7.09 \\
\hline 1990 & $36,264.00$ & $2,294.30$ & 6.33 \\
\hline 1991 & $35,171.60$ & $1,554.20$ & 4.42 \\
\hline 1992 & $52,035.90$ & $2,060.40$ & 3.96 \\
\hline 1993 & $112,100.50$ & $7,999.10$ & 7.14 \\
\hline 1994 & $110,201.00$ & $10,283.10$ & 9.33 \\
\hline 1995 & $153,495.60$ & $12,728.70$ & 8.29 \\
\hline 1996 & $189,000.00$ & $15,351.80$ & 8.12 \\
\hline 1997 & $273,723.20$ & $15,946.00$ & 5.83 \\
\hline 1998 & $376,967.10$ & $26,221.30$ & 7.35 \\
\hline 1999 & $358,103.50$ & $31,508.10$ & 8.82 \\
\hline 2000 & $664,734.30$ & $67,508.10$ & 10.16 \\
\hline 2001 & $918,028.60$ & $59,744.60$ & 6.51 \\
\hline 2002 & $1,188.734 .60$ & $109,455.20$ & 9.21 \\
\hline 2003 & $1,308,287.90$ & $79,436.10$ & 6.07 \\
\hline 2004 & $1,321,580.70$ & $93,767.90$ & 7.10 \\
\hline 2005 & $1,547,272.80$ & $120,035.50$ & 7.76 \\
\hline 2006 & $1,842,600.00$ & $151,723.50$ & 8.2 \\
\hline 2007 & & 137.480 & 6.07 \\
\hline 2008 & & 210.000 & 13.00 \\
\hline 2009 & & 183.360 & - \\
\hline & & \\
\hline
\end{tabular}

Source: Central bank of Nigeria Statistical Bulletin (2010)

The expenditure on education as a whole rose form 190.10 million in 1988 to N151,723.50 in 2006 as shown in table 1, which represents an increase from 5.37 percent to 8.23 percent. Although this is still far from the UNESCO'S recommendation of 26 percent of government budget allocation to education. Also, federal government allocation to federal universities in 1991 and 2006 were N1, 194.4 and N78, 066.8 million respectively which represent an increase of $96 \%$

(See table 2). 
Table 2. Federal Government Budgetary Allocation to Federal Universities in

Nigeria (Some Selected Years)

\begin{tabular}{|l|l|l|l|}
\hline Year & $\begin{array}{l}\text { Total Fed. Govt. } \\
\text { Expenditure (1) } \\
\text { (NM) }\end{array}$ & $\begin{array}{l}\text { Federal Allocation (2) } \\
\text { (NM) }\end{array}$ & (2) as \% of (1) \\
\hline 1991 & $1,554.20$ & $1,194.40$ & 76.80 \\
\hline 1992 & $2,060.40$ & $1,410.60$ & 68.50 \\
\hline 1993 & $7,999.10$ & $5,753.00$ & 71.90 \\
\hline 1994 & $10,283.80$ & $9,650.00$ & 93.80 \\
\hline 1995 & $12,728.70$ & $1,480.40$ & 11.60 \\
\hline 1996 & $15,351.80$ & $3,292.90$ & 21.40 \\
\hline 1997 & $15,946.00$ & $6,260.70$ & 39.20 \\
\hline 1998 & $27,721.30$ & $4,214.40$ & 16.10 \\
\hline 1999 & $31,568.10$ & $29,902.80$ & 66.21 \\
\hline 2000 & $67,556.12$ & $33,843.40$ & 50.09 \\
\hline 2001 & $59,744.20$ & $34,681.30$ & 58.05 \\
\hline 2002 & $109,455.20$ & $32,694.30$ & 29.87 \\
\hline 2006 & $151,723.50$ & $78,066.80$ & 51.60 \\
\hline
\end{tabular}

Source: Okebukola (2003) and Budget Office: Federal Government Annual Budget (2006)

\subsubsection{Working Condition Welfare Scheme and Quality of University Education}

Alli (2000) has observed that poor salaries have been the major bane of the Nigeria university system. According to the theory of motivation, inadequate worker's salaries and poor conditions of service (poor office accommodation and furniture and other welfare packages) bring dissatisfaction in workplaces and thus lower the qualities of inputs delivered. This subsequently leads to brain drain to greener pastures, strike actions by trade union, examination malpractice and so on. On close examination of the ills arising from poor conditions of service, it is established that the quality of the programme is low. But where the workers are comfortable with better salaries and allowances, teaching and learning materials, promotion of staff as at when due, housing and vehicle advances, conducive offices and classrooms and other motivational factors, these will stimulate productivity and the input by the university academic staff and therefore enhance internal quality assurance. These conditions of service and welfare packages help to motivate staff to work harder in the universities. The overall effect of these provisions is the maximization of staff productivity and quality assurance. 


\subsubsection{Staffing and Quality of University Education}

Since no education system may rise above the quality of its teachers (National Policy on Education, 2004), the quality of teachers employed to teach at the educational system is very crucial. The number of qualified staff of both academic and non academic cadres affects the productivity of the staff. Where the number of academic staff is not sufficient, the available staffs are over-loaded thus leading to poor productivity. Poor staffing undermines the issue of quality in university education in Nigeria. The National University Commission (NUC) statistics of 2000 showed a total of 18,328 academic staff in universities to take care of 433,871 students (Federal Ministry of Education, 2003). By NUC staffing norms a total of 33,951 should have been in the system at that time. This means that there was shortfall of 15,718 (46\%) in Nigerian universities in 2000.

According to accreditation reports, (Ekpo, 2002), the staff conditions of most higher institutions are broad-based, that is having more junior staffs than senior staffs. This affects the quality of programmes of higher institutions. Academic staff is the most crucial resource of all the resources required by the knowledge industry. This intellectual resource pool that Nigeria is not able to generate and keep, constrains her universities' capacity to produce quality graduates that can compete in the world market of knowledge.

\section{Review of Traditional/Various Sources of Funding University Education}

3.1 Endowment Funds/Donations: Many institutions of higher learning do establish endowment funds where rich citizens assist in the development of quality education. According to Akangbou (1986), usually prominent citizens donate money to the institutions to be held in their honour perpetuity. The intention is that the donors' name be immortalized in the institutions.

3.2 Tuition Fees: Universities receive a reasonable proportion of their revenue through students' fees, especially with the establishment of Satellite/External campuses all over the place (Obemeata, 1999; Odekunle, 2001). Adeyemi and Osunde (2005) remark that the part-time programmes are offered on a "for-profit" basis (i.e. profit-making venture) which in turn financially subsidize regular students enrolled in Nigerian universities, who are required to pay tuition fees. The proponents of tuition fees believe that it is a means of generating income for the university and at the same time makes the university to be more responsive to students’ needs.

3.3 Undertake Researches, Contracts and Consultancy Services: Institutions of higher learning can also undertake researches for big organizations like the oil firms. Money accruing from these researches can be used by the institutions. Consultancy services can also be undertaken by the institutions and the proceeds from these used to fund the institutions.

3.4 Private Contributors: Parastatals, Big firms, investors in the country, all should be intimated of the need to help fund our higher education so as to have both quantity and quality education. In this awareness campaign, the public should be made to know the gains of education in general to the individuals and to the nation at large. 
3.5 Alumni Association: The old students of an institution are usually very proud to remember their Alma Mata. Old students should be recognized and invited from time to time. The institutions should keep track of their old students to invite them from time to time.

\section{Financial Strategies in the Universities}

The problem that bedevils Nigeria's tertiary education system most has been that of under-funding. It is an established fact that government alone cannot adequately finance the university education. Adeyemi (2005) argues that the current economic conditions have forced the government to issue directives to their universities, asking them to generate additional funds internally to help finance basic university programmes. Having reviewed the various sources of funding the university, it is necessary to examine the other suggested and recommended strategies in funding the university with special emphasis on tuition fees ("Fiscal Justice Principle of Fairness”).

\subsection{Tuition Fees:}

“The Fiscal Justice principle of fairness”

In 2004, the Federal Government, in the National Policy on Education, stressed the importance of alternative sources of funding. According to the policy, it is necessary to supplement government funding of universities. According to Okebukola, Sambo, Adeogun, Quadri, Bankole and Popoola, (2003), government contributed about 55 percent of the total cost of university education (comprising academic, administrative, building and equipment costs) while students contributed the remaining 45 percent of the total cost. While students and parents could consider the 45 percent share of cost by students as high, universities in South Africa have already achieved a situation where students contribute 66 percent of cash of university education (Okebukola, 2003). In 2002, the Nigerian Government issued an order stopping all federal universities from charging tuition fees. As good as this intention is, that is, providing qualitative education to qualified citizens, it is at variance with the income generating "drive” idea of these universities. According to Ajayi and Ayodele (2002), making students pay for what they receive in the university will inject a lot or rationality in their behaviour and consequently reduce wastage in the system. Besides, Akangbou (1985) submitted that charging fees in the higher educational institutions would improve efficiency. In essence, people who benefit from something, be it individuals, governments or corporate organizations are expected to contribute to whatever they benefit from. That is, he that takes the lion share of the benefits desirable from education must also be the person that bears the biggest cost.

The Fiscal Justice principle of fairness is applied to education by Samuel (2003) as that which states that he who takes the lion share on education must bear the biggest cost. This principle corroborates the Benefiter pay principle of fairness which is stressed by Janna (2003),that the people should pay for what they benefit from. According to Janna (2003), the Benefiter supports the policy of "fiscal sustainability" which assumes that, the present generation should forego certain benefits or maintain the benefits but ensure that the benefits are fully paid for by the generation itself. The Fiscal Justice Principle is supported by the 
underlying philosophical concept of justice and fairness which argues that "it is unjust and inequitable for the current generation to impose or pass on debts to the next generation for the benefits that the current generation enjoys. This is so that the well-being and quality of life of the next generation will not be compromised. Hence, it advocates that the present benefiters should pay for what they have taken or gained. It is expected that whoever benefits more from the university education, be it the individual, firm or government should pay more and vice-versa.

According to Samuel (2003), this principle explains the escalating cost of private cost of education as government is drifting away from bearing the cost of education. Some research findings show that the individual benefits more from education. For instance, Samuel (2003), in a study for World Bank on public expenditures in Lagos State schools found out that household unit cost of primary education was N33,000, while the public unit cost was under N3,000. Also Akinyemi (2005), estimating the unit cost of primary education in Lagos State found out that both the private and social cost of education were escalating every year with household spending (private cost) estimated to be more than 70 percent of the total cost and government spending less than 30 percent per child.

Okuwa (2004) opines that since the level of education is proportional to the rate of returns on investment, individuals should be encouraged to pay for higher education. Also, Aromolaran (2002), asserts that with high private rate of returns to post-secondary schooling, students at this level should pay tuition to recoup more of public costs of schooling.

\subsection{Other Strategies}

\subsubsection{Private Sector Participation in Financing University Education}

In the word of Deji-Folutile (2006), "the education system is beset with problem of inadequate funding, collapsed infrastructure and other ills”, thus signifies the government's inability to effectively run the industry. As a way of bailing out of her educational problems, the British Government voted \$15 billion for education in Africa to help the continent achieve the Millennium Development Goals (MDG) by 2015 which was one of the outcomes, of the two-day conference on financing for development in Abuja as reported by the Punch of May 23rd, 2006, in the past ten years, the British had spent $\$ 3.5$ billion for the purpose.

For tertiary institutions to have additional resources there is the need to encourage private sector participation. The World Bank is currently in the task of focusing its attention on private sector participation in the educational development in some countries like Chile, Argentina, Mauritania, Mali, Indonesia, Senegal and El-Salvador. Samuel (2003) confirmed that the improved quality of good and services provided by the private market in the education sub-sector in some of the mentioned countries was a major reason for the preference. The World Bank Report, however, says private education thrives in a market environment where competition, efficiency and profits are the guiding factors. The influence and participation of UNESCO, World Bank, UNDP and UNICEF in the field of education is now too important to be ignored hence our tertiary institutions should therefore mobilize external resources through appropriate bilateral agreements to help contribute to the funding 
of education in Nigeria.

\subsubsection{Macro-Economic Strategy}

The provision of additional resources for education is dependent on a durable and dynamic economy, an economy that is multi-directorial that is non-dependent only on the crude oil but assessing all other sectors of the economy so as to improve the financial capacity of the nation which will invariably affect the tertiary institutions. Samuel (2003) affirms that a multi-directional economy will provide a head long attack on poverty and a macroeconomic strategy will improve the Gross National Products, Gross National Income and the per capital that will enable the government, and the households to have additional resources to efficiently and effectively fund education.

\subsubsection{Partial Deregulation of the Education Sub-Sector:}

The partial deregulation will enable the government to bring in additional resources through various tax funds, private sector financing and managing some facilities and foreign aid and technical assistance etc.

\section{Conclusion}

With the level of underfunding in our tertiary institutions, there is the need to evolve some strategies that will make it possible for the universities to achieve qualitative education. As part of the funding strategies, it is very important to adhere strictly to the principle of fiscal justice or the Benefiters' Payers Principle of Fairness where all stakeholders are to share in the burden of funding university education based on the personal benefit they derive through good employment and higher rates of return of income an average, and the high social status or positions they attain in the society. Also to generate more funds, there is the need to introduce the macroeconomic strategy where the government needs to diversify to other sectors of the economy. There should also be partial deregulation of the education so as to ensure the provision of additional resources for the universities and lastly should encourage private sector participation which will provide additional resources for the institutions.

\section{References}

Adeyemi, K. and Osunde, A. (2005). An Assessment of the Academic Achievement of Students in two Modes of Part-Time Programme in Nigeria. The International Review of Research in Open and Distance Learning 6(2).

Aina, O.I. (2002). Alternative Modes of Financing Higher Education in Nigeria and the Implications for University Governance. Africa Development XXVII (1 \& 2).

Ajayi, I.A. and Ayodele, J.B. (2003). Fundamentals of Educational Management. Ado-Ekiti: Green Line Publishers.

Akangbou, S.D. (1986). Funding Nigeria University, Faculty Lecture Series No. 2, University of Ibadan.

All Africa News: Nigeria (2006). Federal Government Calls on Varsities to Seek Alternative 
Funding. Retrieved from the http://wwwallafrica.com on 19/4/2011

Alli, A. (2000). Teacher Production Utilization and Turnover Patterns in Nigeria. In K. Isyaku, C.M. Amikweze, A.A. Manyaga and G.O. Olokun (Eds). National Commission for Colleges of Education.

Aromolaran A.B. (2002). 'Private Wage Returns to School in Nigeria 1996 - 1999'. Centre Discussion Paper. Retrieved on July 19th 2011 from http://www.econs.yale.edu-center

Babalola, S.K. (2002). Education and National Ethics. A Keynote Address delivered at Workshop on Use of Global Knowledge in University Management, University of Ibadan, 22nd to 23rd April.

Budget Office (2006). 2006 Budgetary Allocation to Education. Federal Republic of Nigeria. Retrieved on 14 June, 2011: from http://www.budgetoffice.gov.ng/pub/edu.pdf

Central Bank of Nigeria (2010). Central Bank of Nigeria. Annual Report and Statement of Account.

Deji-Folutile, B. (2000). Education: Panacea for Decay. The Punch Newspaper, March 14.

Ekpo, A.I. (2002). Quality Control Measures in Nigerian Universities. The Case study of University of Uyo, Uyo Seminar Paper presented at Post-Graduate School, University of Uyo, Uyo.

Federal Government of Nigeria (2004). National Policy on Education, Lagos: Federal Government Press.

Federal Ministry of Education (2002). The Financing of Education in Nigeria, Education Sector Analysis of F.M.E. Abuja. The World Bank and DFID.

Federal Ministry of Education (2003). Education Status Report, May, 2003.

Hinchcliffe, K. (2002). Public Expenditures on Education: Issues Estimates and some Implications, Washington DC: World Bank.

Igwe, S.O. (2007) Quality of Evaluation of Teaching and Learning in Nigeria Education. In B.A. Eheazu \& U.M.O. Ivowi (Eds.) Minimum Standards and Accountability in Nigerian Educational System. Proceedings of the 18th Annual Congress of Academy of Education, University of Port-Harcourt.

Janna, T. (2003). Intergenerational Equity Issues of Principles in the Allocation of Social Resources between this Generation and the Next. Retrieved on May $10^{\text {th }} 2008$ from http://www.aph.gov.au

Maduewesi, E.J. (2002). Unionism and Quality Assurance in the Nigerian Academic System. In O.E. Ekpo and U.M.O. Ivowi (Eds). Unionism and Academic Productivity in the Nigerian Education System. Uyo. Interconnect Publishers.

Nwanna, M.I. (2000). Estimating returns to school quality. Journal of Social Sciences, 24(3),35-41. 
Obemeata, J.O. (1999). Part-Time Programmes: Concept and Development in Nigeria. In O.G. Oshodi, E.T. Ehiametalor, and D. Awambor (Eds). Teacher Education Programmes in Nigeria. Benin-City: University of Benin Publishers.

Odebiyi, A.I. and Aina, O.J. (1999). Alternative Higher Education in Nigeria and Implication for University Governance. Final Report Accra: Association of African Universities (A.A.U.).

Odekunle, K.S. (2001). Funding of University Education Democratic Rule in Nigeria Problems and Prospects. Proceedings of the $12^{\text {th }}$ General Assembly of SSAN.

Okebukola, P. (2003). Issues in Funding University Education in Nigeria. Abuja: NUC. Okebukola, P.; Sambo, A. Adeogun T.A.; Ouadri, O.; Bankole, A.; Popoola, O.O. (2003). Unit Cost of University Education in Nigeria (2001 and 2002). Abuja: NUC.

Olaniyonu O. (2001). Public Finance and Higher Education in Nigeria, Proceedings of the $12^{\text {th }}$ General Assembly of SSAN.

Okwa, O.B. (2004). Private Returns to Higher Education in Nigeria. African Economic Research Consortium, Nairobi, AERC Research Paper.

Onoh, J.K. (1982). Summary of a Seminar Paper on Profit Making Centers in University Management, CEREMAC, University of Ibadan.

UNESCO. (2000).Higher education in the $21^{\text {st }}$ century: vision and mission. Retrieved on May $2^{\text {nd }} 2007$ from htt://www.upo.unesco.org

Samuel, T. (2003). Strategies for Raising Additional Resources for Education. Education Today, Vol. 10, No.1, June, p. 40 - 43.

Tamuno, T.K. (1987). Management of the Universities in Nigeria: A look at the past, the present and the future. In Resources Management in the University System, Zaria: Proceedings of the NUC/CVC/BC International Seminar. 